\title{
Dynamic Cytoskeletal Glycosylation and Neurodegenerative Disease
}

\author{
ダイナミックな細胞骨格のグリコシル化と神経変性疾患
}

\author{
Arnold, C. Shane ; and Hart, Gerald W.* \\ Dept. of Biological Chemistry The Johns Hopkins University School of Medicine \\ Baltimore, Maryland 21205, USA \\ FAX: 1-410-614-8804, E-mail: gwhart@bs.jhmi.edu
}

Key words:Alzheimer's disease, cytoskeleton, O-GlcNAc, tau, phosphorylation, protein glycosylation

\begin{abstract}
$O$-GlcNAcylation of nucleoplasmic and cytoplasmic proteins is a ubiquitous and highly dynamic modification. It entails the attachment of a single $O$-linked $N$-acetylglucosamine $(O$-GlcNAc) moiety $O$-glycosidically linked to side-chain hydroxyls of serine and threonine residues. The rapidly expanding list of $O$-GlcNAcylated proteins includes RNA Polymerase II, nuclear pore, heat shock, and tumor suppressor proteins, nuclear oncogenes, and numerous cytoskeletal and membrane associated proteins. Many sites of $O$-GlcNAc addition are similar to consensus sites of protein phosphorylation, and in some cases identical. Accordingly, $O$-GlcNAcylation and $O$-phosphorylation appear to be reciprocally related on some proteins. All $O$ GlcNAcylated proteins are phosphoproteins which assemble into tightly regulated reversible multi-protein complexes. Several $O$-GlcNAcylated proteins are key components involved in cytoskeletal assembly and organization, and defects in their regulated multimerization are implicated in several neurodegenerative disorders. Thus, abnormal cytoskeletal $O$-GlcNAcylation may promote defects in regulated protein multimerization and potentiate disease.
\end{abstract}

要 約

核や細胞質タンパク質の $O$-GlcNAc 化は、偏在する高度に ダイナミックな修飾である。それは、1 個の $O$-結合型 $N$-アセ チルグルコサミン $(O-G l c N A c)$ が、Oグリコシド結合によって、 Ser または Thr 残基の側鎖の水酸基に結合することである。急 速に増加している $O$-GlcNAc 化タンパク質のリストには、RNA ポリメラーゼII、核孔タンパク質、熱ショックタンパク質、腫 瘍抑制タンパク質、核癌遺伝子産物、および膨大な数の神経細 胞骨格および膜結合型のタンパク質がある。O-GlcNAcが結合す る多くの部位は、タンパク質のリン酸化のコンセンサス部位に 類似しており、一致している場合もある。したがって、いくつ かのタンパク質において、O-GlcNAc 化とリン酸化に相反する関 係があるように見える。すべての O-GlcNAc 化タンパク質はり ン酸化タンパク質であり、集合して厳密に調節された、複数夕 ンパク質の可逆的な複合体を形成する。いくつかの $O$-GlcNAc 化タンパク質は、細胞骨格の集合や構成に携わる鍵となる成分 であり、それらの調節された多量体化における欠陥は、いくつ かの神経変性異常に関与している。それゆえに、細胞骨格の異 常な $O$-GlcNAc 化は、調節されたタンパク質の多量体形成を損 ない、疾患を進行させるであろう。

\section{A. Introduction}

\section{A. 序}

The serendipitous discovery of $O$-linked $N$ acetylglucosamine $(O \text {-GlcNAc })^{1}$ while probing the cell surface of T-lymphocytes with $\beta(1,4)$-galactosyltransferase $(\beta(1,4) \mathrm{GT})$ has dramatically expanded the realm of protein glycosylation. Unlike secretory or lumenal $N$-linked glycoproteins, $O$-GlcNAc is attached to serine and threonine residues of nuclear and cytoplasmic proteins (For reviews see: 1-6). The diverse and wide-

$\beta(1,4)$-ガラクトース転移酵素 $(\beta(1,4) \mathrm{GT})$ を用いて T リン 八゚球細胞表面を研究している時、 $O$-結合型 $N$-アセチルグルコサ ミン $(O-$ GlcNAc) が思いがけなく発見され、タンパク質のグリコ シル化の分野がめざましく発展した。分泌型の、または腔の $N$ 結合型糖タンパク質とは異なり、O-GlcNAc は核や細胞質タンパ ク質の Ser または Thr 残基に結合する (総説1-6を参照)。O-

* To whom correspondence should be addressed.

1 The abbreviations used are: $O$-GlcNAc, $O$-linked $N$-acetylglucosamine; $\beta(1,4) \mathrm{GT}, \beta(1,4)$ galactosyltransferase; Con A, Concanavilin A; PMA, Phorbol 12-myristate 13-acetate; PUGNAc, $O$-(2-acetamido-2-deoxy-D-glucopyranosylidene) amino- $N$-phenylcarbamate; MAP, microtubule-associated protein; AP3, assembly protein 3; HPAEC-PAD, high pH anion exchange chromatography- pulsed amperometric detection; RP-HPLC, reverse phase-high pressure liquid chromatography; OGT, $O$-GlcNAc transferase; TPR, tetratricopeptide repeat; CaMKII,

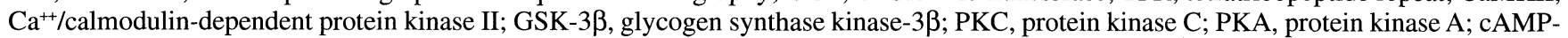
PK, cAMP dependant protein kinase; IF, intermediate filament; NF, neurofilament; ESMS, electrospray mass spectrometry; MALDI-TOF, matrix -assisted laser desorption ionization time of flight; $\mathrm{AD}$, Alzheimer's disease; NFT, neurofibrillary tangle; $\beta$-APP, $\beta$-amyloid precursor protein; PHFs, paired helical filaments; PHF-Tau-paired helical filament tau; FTDP-17, frontotemporal dementia-17. 
spread distribution of $O$-GlcNAcylated proteins is represented by its presence in diverse organisms such as: viruses, fungi, and protozoa. Among the $O$-GlcNAcylated proteins identified to date are a family of dynamic filamentous phosphoproteins which constitute the cytoskeleton. Phosphorylation regulates their interactions within the cell, however, their abnormal hyperphosphorylation leads to the formation of insoluble filamentous aggregates and is associated with the pathology of a number of neurodegenerative disorders. Interestingly, phosphorylation and glycosylation appear to be reciprocally related within the cytoskeleton. In this review the following focal points will be discussed: the dynamic and widespread distribution of $O$ GlcNAc, the enzymatic regulation of protein $O$-GlcNAcylation, (Ser,Thr)-O-GlcNAcylation and (Ser,Thr)-O-phosphorylation, $O$-GlcNAcylated cytoskeletal proteins, and ultimately how $O$ GlcNAcylation of the cytoskeleton may be important in many neurodegenerative disorders such as Alzheimer's disease.

\section{B. $O$-GlcNAc Is Dynamic and Abundant}

Unlike the addition of $N$-linked and $O$-linked oligosaccharides, the $O$-GlcNAcylation of proteins is a highly dynamic process (Fig. 1). For instance, in pulse- chase experiments with U3.73-MG astroglioma cells, $100 \%$ of the $O$-linked GlcNAc on $\alpha \mathrm{B}$-crystallins turned over in $20 \mathrm{~h}$ while the polypeptide core levels remained unchanged over a $40 \mathrm{~h}$ chase (7). Likewise, acid hydrolysis of keratins $(\mathrm{K} 8, \mathrm{~K} 18)$ purified from $\left[{ }^{3} \mathrm{H}\right]$ glucosaminelabeled HT29 human colonic cells revealed that both the biosynthesis and degradation rates of $O$-GlcNAc were much faster than the polypeptide (8). $O$-GlcNAc levels also change in response to various cellular stimuli. Kearse and Hart observed a rapid reduction in the $O$-GlcNAcylation of cytoplasmic proteins released from digitonin permeabilized T-lymphocytes when stimulated with Concanavalin A (Con A) (9). Additionally, $O$ GlcNAcylation of nuclear proteins rapidly increased in $\mathrm{T}$ cell
GlcNAc 化タンパク質の、多様で広範囲に及ぶ分布は、その他の 生物、例えばウイルスや菌類、原生動物類などにおける存在に よって示される。今まで同定された O-GlcNAc 化タンパク質 は、細胞骨格を構成するダイナミックな繊維状リン酸化タンパ ク質の一群である。リン酸化は、それらのタンパク質の細胞内 での相互作用を調節するが、異常な過度のリン酸化は不溶性の 纎維状凝集体の形成を引き起こし、多くの神経変性異常の病理 に関係する。興味深いことに、リン酸化とグリコシル化は細胞 骨格内で相反関係があるようだ。この論文中では、O-GlcNAcの ダイナミックで広範囲な分布、 $O$-GlcNAc 化タンパク質の酵素的 調節、(Ser、Thr)-O-GlcNAc 化と (Ser、Thr)-O-リン酸化、OGlcNAc 化細胞骨格タンパク質、ならびに最終的には細胞骨格の $O$-GlcNAc化がアルッハイマー病のような多くの神経変性異常に おいて、どれほど重要かについて焦点を当てて議論する。

\section{B. ダイナミックで豊富なO-GlcNAc}

タンパク質の $O$-GlcNAc 化は、 $N$-や $O$-結合型オリゴ糖鎖の 付加と違い、非常にダイナミックな過程である(図 1 )。例えば U373-MG 血管神経膠腫細胞を用いたパルスチェイス実験では、 ポリペプチドコアのレベルは 40 時間にわたって変化しなかった のに対し、 $\alpha \mathrm{B}-$ クリスタリン上の $O$ - 結合型 GlcNAc は 20 時間

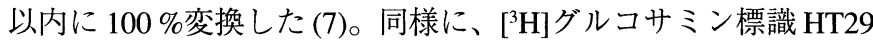
ヒト結腸細胞から精製したケラチン $(\mathrm{K} 8 、 \mathrm{~K} 18)$ の酸加水分解で は、O-GlcNAc の生合成と分解の両方の速度がポリペプチドより もかなり速いことが明らかになった (8)。O-GlcNAc のレベルは さまざまな細胞刺激に応じても変化する。Kearse と Hartは、ジ ギトニン透過性 Tリンパ球から分泌される、細胞質タンパク質 の O-GlcNAc 化が、コンカナバリン A（ConA）の刺激により急 速に減少することを見いだした (9)。その上、 $\mathrm{T}$ 細胞ハイブリ

\section{O-GlcNAcylation is Dynamic}

\section{O-Linked N-Acetylglucosamine}

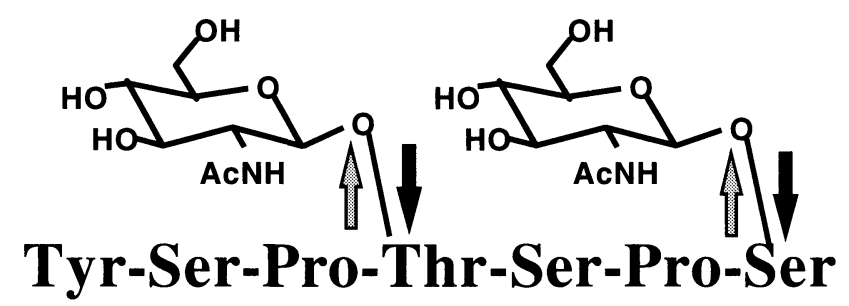

Fig. 1. The dynamics of protein $\boldsymbol{O}$-GIcNAcylation. The $O$-GlcNAc modification occurs on serine and threonine residues, and turns over more rapidly than the protein backbone. 
hybridomas stimulated with Phorbol 12-myristate 13-acetate (PMA) and the calcium ionophore, ionomyocin. Furthermore, treatment of HT29 cells with $O$-(2 acetamido-2-deoxy-Dglucopyranosylidene) amino- $N$-phenylcarbamate (PUGNAc), a potent inhibitor of the enzyme responsible for the removal of $O$-GlcNAc, caused an approximate two fold increase in $O$ GlcNAc levels (10). Changes in the $O$-GlcNAcylation of proteins also occur during the cell cycle. For example, the amount of $O$-GlcNAc on human keratin K18 increases seven fold in mitotically arrested HT29 cells, whereas during S-phase, its glycosylation is unchanged (11). Collectively, these data clearly illustrate the dynamics of $O$-GlcNAcylation, and establish this as a unique form of protein glycosylation. In addition, this evidence suggests that $O$-GlcNAc is a regulatory modification.

The number of proteins known to be modified with $O$ GlcNAc is continuously growing. The majority of eukaryotic $O$-GlcNAcylated proteins reside within the nucleus. In fact, approximately $54 \%$ of $O$-linked GlcNAc (pmol $/ \mathrm{mg}$ ) is in the nucleus of an average liver cell (12). RNA Polymerase II and its associated transcription factors are a few of the many nuclear glycosylated proteins (13). Nuclear pore proteins, including the heavily glycosylated nucleoporin p62, are also modified with $O$-GlcNAc $(14,15)$. Moreover, the tumor suppressor p53 (16), oncoproteins c-myc (17) and v-Erb-a (18), as well as the estrogen receptor (19) and SV40 large T antigen (20), are all $O$ GlcNAcylated.

In addition to nuclear proteins, $O$-GlcNAcylation also occurs on cytoskeletal, cytosolic, and membranous proteins throughout the cytoplasm. Several $O$-GlcNAcylated proteins have been identified within the cytoskeleton (Table I), including a dynamic network of intracellular proteins involved in various functions from muscle contraction, axonal transport, to neu-
ドーマ中の核タンパク質の O-GlcNAc 化は、ホルボール12-ミリ スチン酸エステル 13-酢酸 (PMA) やカルシウムイオノホア、イ オノマイシンの刺激により急速に増加した。さらに、HT29 細胞 を、O-GlcNAc を除去する酵素の強力な阻害剂である $O-(2-$ ア セ トアミド-2-デオキシ-D-グルコピラノシリデン)アミノ- $N$-カルバ ミン酸フェニル (PUGNAc) で処理することにより、O-GlcNAcレ ベルでおよそ 2 倍の増加がみられた $(10) 。$ 細胞周期の間でも夕 ンパク質の O-GlcNAc 化の変化は起きる。例えば、HT29 細胞の 分裂を停止させると、ヒトケラチン K18 上の O-GlcNAc の量は 7 倍に増加するが、一方では $\mathrm{S}$ 期の間そのグリコシル化は変化 しない (11)。まとめると、これらのデータは O-GlcNAc 化のダ イナミクスを明瞭に例証しており、これがタンパク質のグリコ シル化の独特な形態であることを確立する。さらにこの証拠 は、O-GlcNAc とは調節修飾であることを示唆している。

O-GlcNAcにより修飾されることが知られているタンパク質 の数は、継続的に増えている。真核生物の O-GlcNAc 化タンパ ク質の大多数は核内に存在する。実際には $O$-結合型 GlcNAc $(\mathrm{pmol} / \mathrm{mg})$ のおよそ 54 \%は、普通の肝細胞の核内にある (12)。 RNA ポリメラーゼII とそれに結合した転写因子は、多くのグリ コシル化核タンパク質のうちの一部である (13)。グリコシル化 を高度に受けた、ヌクレオポリン 62 を含む核膜孔タンパク質 もまた、O-GlcNAcにより修飾される $(14 、 15)$ 。さらに腫瘍抑制 因子 p53 (16)、腫瘍タンパク質の c-myc (17) と v-Erb-a (18) は、 エストロゲン受容体 (19)、SV40の大きな T抗原 (20) と同様に、 すべて O-GlcNAc 化を受ける。

核タンパク質に加え、O-GlcNAc 化は細胞質中の細胞骨格、 細胞質ゾル、膜タンパク質に対しても起きる。いくつかの $O$ GlcNAc 化タンパク質は、細胞骨格内で同定され (表 I)、筋肉の 収縮、軸索の輸送から神経筋シナプス形成までの、さまざまな 機能に関係する細胞内タンパク質のダイナミックネットワーク

Table I. A list of some $\boldsymbol{O}$-GlcNAcylated proteins found within the cytoskeleton. Among them are intermediate filaments, microtubule-associated proteins, and actin-membrane bridging proteins.

Identified O-GlcNAcylated Cytoskeletal Proteins

Ankyrin $_{\mathrm{G}}$

Cytokeratins 13, 8, 18

Neurofilaments $L, H$,

M

Erythr. Band 4.1

Synapsin I

MAP Proteins:

MAP1, MAP2, MAP4
Tau

Talin

Vinculin

$\alpha$-Crystallins

B-Amyloid Precursor

Clathrin AP3 
romuscular junction formation. Microtubule- associated proteins (MAPs), homologous phosphoproteins (21-23) which facilitate the polymerization of tubulin (24), are among the many $O$-GlcNAcylated proteins which constitute the cytoskeleton. The high molecular weight MAPs: MAP1, MAP2, and MAP4 (25), as well as the lower molecular weight family of tau proteins (26), are all modified with $O$-GlcNAc. The intermediate filament keratins, $\mathrm{K} 13, \mathrm{~K} 8$, and $\mathrm{K} 18$ which are involved in maintaining the structural integrity of cells, are also $O$-GlcNAcylated. The neurofilaments NF-L, NF-M, and NF-H which are important in nerve conduction velocity and implicated in motor neuron diseases, likewise are $O$-GlcNAcylated $(27,28)$. In addition, ankyrins which are targeted to Nodes of Ranvier, specific domains within myelinated axons, are modified with $O$-GlcNAc (29). Other glycosylated cytoskeletal proteins include the $\alpha A$ and $\alpha \mathrm{B}$-crystallins $(7,30)$, the erythrocyte membrane protein Band 4.1 (31), talin (32), vinculin (33), synapsin I (34), and clathrin assembly protein 3 (AP3) (35-37). Cumulatively, it is clearly evident that there are numerous nuclear and cytoskeletal proteins modified with this dynamic post-translational modification. Further investigating these proteins will ultimately reveal the many multi-functional roles of $O$-GlcNAc.

\section{The Enzymatic Regulation of $\boldsymbol{O}$-GlcNAc}

Studying the metabolism of $O$-GlcNAc first requires an identification and understanding of the enzymes involved. Two enzymatic activities, a UDP-GlcNAc:polypeptide $N$ acetylglucosaminyl- transferase $(O$-GlcNAc transferase) and an $O$-GlcNAc specific $\beta$-D- $N$-acetylglucosaminidase $(O$ GlcNAcase) are responsible for the addition and removal of $O$ GlcNAc to and from nuclear and cytoplasmic proteins, respectively. $O$-GlcNAc transferase was originally purified from rat liver (38), and subsequently cloned from a rat liver cDNA library (39) and from C. elegans (40). O-GlcNAcase has also been recently purified and characterized from rat spleen cytosol (41). Due to the highly dynamic nature of this modification, both enzymes regulating $O$-GlcNAcylation must be tightly controlled, and therefore thoroughly characterized.

The $O$-GlcNAc transferase (OGT) was originally purified to apparent homogeneity from rat liver cytosol, and is a heterotrimeric complex containing one $78 \mathrm{kDa}(\beta)$ and two catalytic $110 \mathrm{kDa}(\alpha)$ subunits. Both of the enzyme's subunits are $O$-GlcNAcylated as well as tyrosine phosphorylated. The enzyme has an unusual high affinity for the donor substrate UDPGlcNAc $\left(K_{\mathrm{m}}=545 \mathrm{nM}\right)$, and appears to have multiple affinities for UDP-GlcNAc accross a broad physiological range (42) which gives it a competitive advantage over lumenal UDP-GlcNAc transporters. OGT is inhibited by low micromolar concentrations of UDP, UTP, and UDP-GlcNAc. The enzyme has recently been cloned from $C$. elegans, human and rat liver cDNA libraries, and is evolutionarily conserved. However, at the
を含んでいる。相同性を持つリン酸化タンパク質である微小管 結合タンパク質 (MAPs) (21-23) は、チューブリンの多量体化を 促進するが (24)、細胞骨格を構成する多くの O-GlcNAc 化タン パク質の中の一群である。高分子量の MAPs：MAP1、MAP2、 MAP4 (25) は、低分子量のタウタンパク質ファミリー (26) と同 様に、すべて O-GlcNAc 化される。細胞の構造的完全性の維持 に関わる、中間フィラメントケラチン、K13、K8、K18 もまた $O-$ GlcNAc 化される。神経伝達速度において重要で、運動ニューロ ン疾患に関するニューロフィラメント NF-L、NF-M、NF-H も同様 にO-GlcNAc 修飾される $(27 、 28)$ 。さらに、有髄軸索内の特異的 ドメインであるランビエ絞輪に局在するアンキリンも、OGlcNAc 修飾される (29)。その他のグリコシル化細胞骨格タンパ ク質には、 $\alpha \mathrm{A}$ と $\alpha \mathrm{B}$-クリスタリン (7、30)、赤血球膜タンパク質 Band 4.1 (31)、テーリン (32)、ビンキュリン (33)、シナプシン I (34)、クラスリン集合タンパク質 3 (AP3) (35-37) が含まれる。 このダイナミックな翻訳後修飾を受けた多くの核、細胞骨格夕 ンパク質があるという証拠が、徐々に明らかになっていく。こ れらのタンパク質のさらなる研究により、最終的に、O-GlcNAc の多機能な役割が明らかになるだろう。

\section{O-GlcNAcの酵素調節}

O-GlcNAcの代謝について研究するためには、まずはじめに 関与する酵素を同定し、理解することが必要である。2つの酥素 活性、UDP-GIcNAc : ポリペプチド $N$-アセチルグルコサミン転 移酵素 ( $O$-GlcNAc 転移酵素) と $O$-GlcNAc 特異的 $\beta-D-N$ ア セチ ルグルコサミニダーゼ (O-GlcNAcase) は、それぞれ核や細胞質 タンパク質に対する、O-GlcNAcの付加または除去を触媒する。 $O-G 1 c N A c$ 転移酵素は、もともとラットの肝臟から精製され (38)、その後ラット肝臓 cDNA ライブラリー (39)、および線虫 C. elegans (40) からクローニングされた。O-GlcNAcase は最近、 ラット脾臓の細胞質ゾル (41)からも精製され、特徵づけが行わ れた。O-GlcNAc 修飾は非常にダイナミックであるため、これを 調節する両酵素は、厳密に制御されているはずであり、徹底的 にこれらの性質を調べなければならない。

$O-$ GlcNAc 転移酵素 (OGT) は、もともとラットの肝臓の細 胞質ゾルからほぼ均一に精製され、1つの $78 \mathrm{kDa}(\beta)$ のサブユ ニットと、2つの $110 \mathrm{kDa}(\alpha)$ の触媒サブユニットからなる、 ヘテロ三量体である。両酵素のサブユニットは、チロシンがリ ン酸化されるのと同様、O-GlcNAc 化されている。酵素は、ド ナー基質 UDP-GIcNAcに対し非常に高い親和性を持っていて $\left(K_{\mathrm{m}}=545 \mathrm{nM}\right)$ 、生理学的に広範囲にわたる複数の親和力を UDPGlcNAcに対し示すため (42)、管腔の UDP-GIcNAc 輸送体より も競争的に優位である。OGT は、低 $\mu \mathrm{M}$ 濃度の UDP、UTP、お よびUDP-GlcNAc で阻害される。その酵素は最近、C. elegans お よびヒト・ラット肝臓 cDNA ライブラリーからクローニングさ れ、また進化上で保存されている。しかしながら、ポリペプチ 
polypeptide level it is uniquely unlike any other known glycosyltransferase. OGT contains an uncharacteristically high number of tetratricopeptide repeats (TPR), a structural motif implicated in both intra and inter-molecular protein- protein interactions (43). Consequently, the regulation of the enzyme's substrate specificity may depend upon its TPR- associated factors. OGT message, protein, and activity are present in numerous tissues including: brain, heart, kidney, liver, lung, spleen, pancreas and thymus. Among these, OGT is enriched in brain, thymus, and the pancreas.

The enzyme involved in $O$-GlcNAc removal, $O$ GlcNAcase, has been purified over 20,000-fold from rat spleen cytosol. $O$-GlcNAcase is a heterodimeric enzyme consisting of a $54 \mathrm{kDa}(\alpha)$ subunit and a $51 \mathrm{kDa}(\beta)$ subunit. Unlike other hexosaminidases, this $\beta$-D-N acetylglucosaminidase ( $O$-GlcNAcase) has a neutral $\mathrm{pH}$ optimum (pH 6.4), and is not inhibited by GalNAc or its analogs. $O$-GlcNAcase is however effectively inhibited by GlcNAc $\left(K_{\mathrm{i}}=3.9 \mathrm{mM}\right)$ and its analogs 1-azido-GlcNAc $\left(K_{\mathrm{i}}=\right.$ $1.14 \mathrm{mM}), 1$-amino-GlcNAc $\left(K_{\mathrm{i}}=151 \mu \mathrm{M}\right)$, and PUGNAc $\left(K_{\mathrm{i}}=\right.$ $52 \mathrm{nM}) . O$-GlcNAcase activity is present in many rat tissues including: liver, kidney, heart, lung, uterus, and spinal cord, but the enzyme is most enriched in the spleen and brain. The cloning of the rat cytosolic enzyme is in progress.

\section{D. (Ser, Thr)-O-GlcNAcylation and (Ser, Thr)-O-Phospho- rylation}

Analogous to (Ser/Thr) protein kinases and protein phosphatases which modulate the phosphorylation state of proteins, OGT and $O$-GlcNAcase regulate the dynamic $O$-GlcNAcylation of proteins (Fig. 2). A large number of $O$-GlcNAcylation sites
ドレベルでは、他の既知の糖転移酵素とは比類なく異なってい る。OGTは、分子内抢よび分子間タンパク質-タンパク質相互作 用に関係する構造モチーフである、テトラトリコペプチドの繰 り返し (TPR) を類まれなほど数多く持っている (43)。したがっ て、酵素の基質特異性の調節は、その TPR 結合因子に依存して いる。OGTのメッセージ、タンパク質、ならびに活性は、脳、 心臓、腎臓、肝臓、肺、脾臓、膵臓、胸腺など、多くの組織に 存在する。これらの中で OGT は、脳、胸腺、膵臓に豊富に存在 する。

$O$-GlcNAc を除去する酵素の $O$-GlcNAcase は、ラットの脾 臟細胞質ゾルから 20,000 倍以上に精製された。 $O$-GlcNAcase は、 $54 \mathrm{kDa}(\alpha)$ のサブユニットと $51 \mathrm{kDa}(\beta)$ のサブユニットから なる、へテロ二量体酵素である。他のへキソサミニダーゼと違 い、この $\beta$-D-N-アセチルグルコサミニダーゼ (O-GlcNAcase) は、中性領域 $(\mathrm{pH}$ 6.4) に最適 $\mathrm{pH}$ を持ち、GalNAc やその類似化 合物による阻害を受けない。しかしながら、O-GlcNAcは、 GlcNAc $\left(K_{\mathrm{i}}=3.9 \mathrm{mM}\right)$ とその類似化合物である 1-アジド-GlcNAc $\left.\left(K_{\mathrm{i}}=1.14 \mathrm{mM}\right) 、 1-ア ミ\right)-G l c N A c\left(K_{\mathrm{i}}=151 \mu \mathrm{M}\right)$ 、および PUGNAc $\left(K_{\mathrm{i}}=52 \mathrm{nM}\right)$ により、効果的に阻害される。O-GlcNAcase の活性 は、ラットの多くの組織、肝臓、腎臓、心臓、肺、子宮、およ び疌髄に存在するが、最も豊富にあるのは脾臓と脳である。 ラットの細胞質ゾルの酵素のクローニングは、進行中である。

D. (Ser、Thr)-O-GlcNAc化と (Ser、Thr)-Oーリン酸化

タンパク質のリン酸化状態を調節する、 $(\mathrm{Ser} / \mathrm{Thr})$ プロテイ ンキナーゼとプロテインホスファターゼに類似して、OGT と $O$ GlcNAcase は、タンパク質のダイナミックな O-GlcNAc 化を調 節する (図2)。多数の O-GlcNAc 化部位は、プロリン指向性の

\section{O-GlcNAcylation}

\section{and Protein Phosphorylation}

Fig. 2. Protein $O$-GlcNAcylation and $O$-phosphorylation. A model representing the multiple pathways involved in regulating the post-translational state of $O$-GlcNAcylated phosphoproteins. Analogous to Ser/Thr protein kinases and phosphatases which attach and remove phosphates, are the $O$-GlcNAc transferase and $O$-GlcNAcase which likewise attach and remove $O$-GlcNAc.

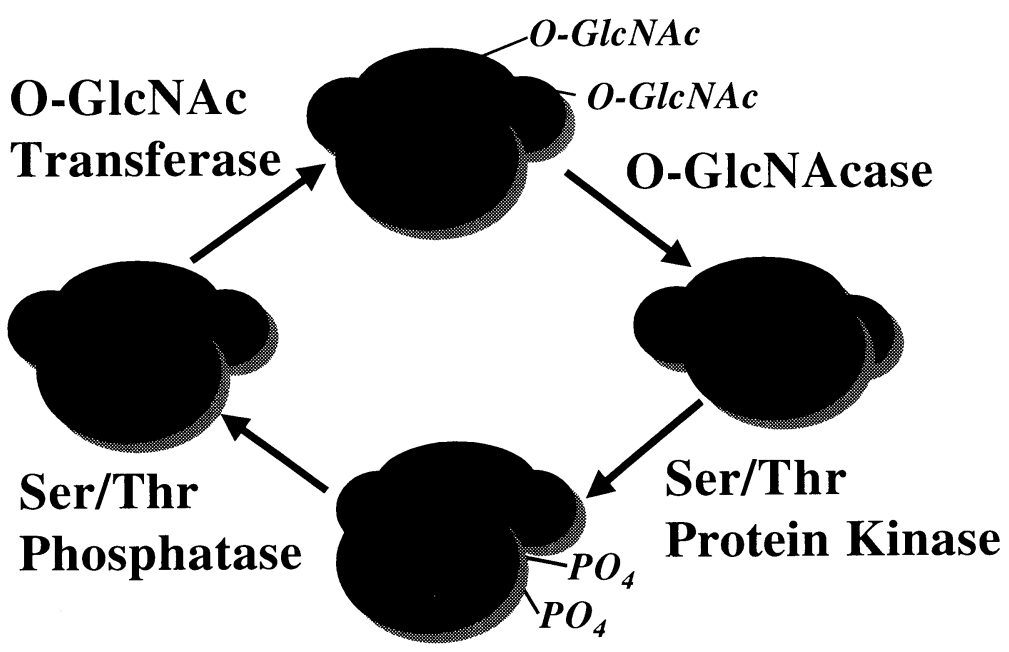


resemble proline-directed (Ser/ Thr) protein kinase sites of phosphorylation (5), and lie at or near Pro-Val-(Ser/ Thr) sequences. These include sites from the human serum response factor (44), $\alpha A$ and $\alpha B$ crystallins $(30,7)$, and from the head domains of rat neurofilaments NF-L and NF-M (27). Notably, other $O$ GlcNAcylation sites appear to have no definitive identifiable consensus sequence (5).

Because $O$-GlcNAc levels change rapidly upon stimulation with mitogens as well as during the cell cycle, protein $O$ GlcNAcylation has been proposed to be analogous to protein phosphorylation. For instance, both $O$-GlcNAcylation and phosphorylation of human keratins $(\mathrm{K} 8, \mathrm{~K} 18)$ increase in $\mathrm{G}_{2} / \mathrm{M}$ arrested HT29 cells $(11,45)$. $O$-GlcNAcylation has also been proposed to regulate the phosphorylation state of proteins by steric hinderance or by blocking access to nearby hydroxyl groups. For. example, the glycosylation sites of synapsin I, a synaptic vesicle associated protein, lie within domains involved in actin binding and closely bracket neighboring $\mathrm{Ca}^{++} /$calmodulin-dependent protein kinase II (CaMKII) sites of phosphorylation (34). Likewise, $O$-GlcNAc sites overlap phosphorylation sites within the head domains of neurofilaments NF-M, and NF-H. The neurofilament NF-H is also extensively $O$-GlcNAcylated in a region consisting of 52 Lys-Ser-Pro repeats, a region that is also highly phosphorylated. Although, it is not clear if these forms of neurofilament NF-H molecules, $O$-GlcNAcylated and phosphorylated, exist as two distinct subpopulations. The close proximity of $\mathrm{N}$-acetylglucosamine moieties to nearby sites of phosphorylation hints at a novel mechanism by which the overall post-translational state of these proteins might be regulated.

Due to the fact that many sites of $O$-GlcNAcylation are similar to MAP kinase and glycogen synthase kinase-3 $\beta$ (GSK$3 \beta$ ) sites of phosphorylation, and in some cases identical, these two modifications have also been suggested to have a reciprocal relationship. For example, the major site of $O$-GlcNAcylation on the oncogenic transcription factor c-myc is within its transactivation domain (17) at Thr-58 (46), a known in vivo phosphorylation site and the major mutational "hot- spot" associated with tumorigenic lymphomas. Consistent with the hypothesis of $O$-GlcNAcylation and $O$-phosphorylation reciprocity, mutually exclusive subpopulations of $O$-GlcNAcylated and $O$-phosphorylated forms of RNA Polymerase II have been isolated from calf thymus (13). Furthermore, increased $O$-GlcNAcylation of the transcription factor $\mathrm{Sp} 1$ by treatment of HT29 cells with PUGNAc, resulted in a concomitant marked reduction in Sp1 _.phosphorylation (10).

Investigators have recently addressed the question of $O$ GlcNAcylation and phosphorylation reciprocity by testing the effects of both protein kinase inhibitors and activators on protein $O$-GlcNAcylation in cerebellar neurons (47). After drug treatments, cells were fractionated into a membrane and cytosolic fraction, and a detergent insoluble cytoskeletal fraction. When
(Ser/Thr) プロテインキナーゼによるリン酸化部位に類似してお り (5) Pro-Val-(Ser/Thr) 配列、またはその近くに存在している。 これらはヒト血清応答因子 (44)、 $\alpha \mathrm{A}$ と $\alpha \mathrm{B}$ クリスタリン (30、 7)、およびラットニューロフィラメント NF-L と NF-M の頭部 ドメイン (27) からの部位を含んでいる。特に、その他の $O-$ GlcNAc化部位には、確固とした同定可能な共通配列は見つから ないようだ(5)。

$O$-GlcNAc の量は細胞周期中と同様に、分裂促進因子による 刺激によってすばやく変わるので、タンパク質 O-GlcNAc 化 は、タンパク質リン酸化と類似すると提案されている。例え ば、ヒトケラチン (K8、K18)の O-GlcNAc 化とリン酸化は、G2/ M 期で停止した HT29 細胞に扔いて増加する(11、45)。O-GlcNAc 化はまた、立体障害や隣接水酸基への酵素の近接を妨げること によって、タンパク質のリン酸化状態を調節すると提案されて いる。例えば、シナプシン I、シナプス小胞結合タンパク質の グリコシル化部位は、アクチン結合に関わるドメイン内に存在

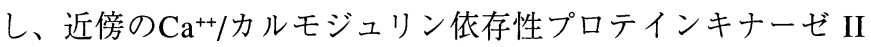
(CaMKII) リン酸化部位をまとめて含んでしまう。同様に、OGlcNAc 部位はニューロフィラメント NF-M、およびNF-H の頭 部ドメイン中のリン酸化部位に重複している(34)。ニューロフィ ラメント NF-H はまた、高度にリン酸化も受けうる 52 回の LysSer-Proの繰り返しから成る領域で、広範囲に $O$-GlcNAc 化を受 ける。けれども、O-GlcNAc 化とリン酸化されたニューロフィラ メント NF-H 分子の二つの型が、それぞれ別個の集団として存 在するかどうかは明らかではない。N-アセチルグルコサミン部 分が隣接したリン酸化部位の近くにあることは、これらのタン パク質の翻訳後状態が全体として調節されるという、新しい機 構があることを暗示している。

O-GlcNAc 化の多くの部位は、MAP キナーゼとグリコーゲ ンシンターゼキナーゼ $3 \beta(G S K-3 \beta)$ によるリン酸化部位と類似 しており、時には全く一致している。これらの修飾はまた、相 反関係にあることが示唆されている。例えば、発ガン性転写因 子 c-myc 上での O-GlcNAc 化を受ける主な部位は転写活性ドメ イン内(17)にある Thr-58(46) で、既知の in vivo リン酸化部位で あり、腫瘍を発生するリンパ腫に関連した主な突然変異の “hotspot”である。O-GlcNAc 化とO-リン酸化の反作用仮説と一致 して、RNA ポリメラーゼ II の互いに排他的に O-GlcNAc 化と $O$-リン酸化された形の副次集団が、子牛胸腺から分離されてい る(13)。さらに、PUGNAcによって HT29 細胞を処理すること により、転写因子 Sp1 の O-GlcNAc 化が増加すると同時に Sp1 リン酸化が著しく減少した(10)。

研究者は最近、O-GlcNAc 化とリン酸化の相反性の問題に、 小脳神経細胞でのタンパク質 $O$-GlcNAc 化におけるプロテイン キナーゼ阻害剤と活性化因子との影響を調べることで取りか かった(47)。薬物処理後、細胞は、膜と細胞質ゾル画分、界面活 性剂不溶性の細胞骨格画分に分画された。小脳神経細胞を、 
cerebellar neurons were treated with either PMA, a protein kinase $\mathrm{C}$ (PKC)activator, or dibutyryl cAMP, a cyclic-AMP dependent protein kinase (PKA) activator, protein $O$ GlcNAcylation within the cytoskeletal fraction decreased by 50 $60 \%$. Conversely, inhibition of PKC with bis-indoylmaleimide produced a $45 \%$ increase in cytoskeletal $O$-GlcNAcylation, and PKA inhibition doubled the amount of $O$-GlcNAc detected in the cytoskeletal fraction. Consequently, protein phosphorylation and $O$-GlcNAcylation appear to be reciprocally related within the cytoskeleton. Surprisingly, treatment with these compounds appeared to have little effect on cytosolic or membrane $O$-GlcNAcylation in these studies. Clearly, the complexity of the relationship between these two post-translational modifications is dependant upon which proteins are modified as well as which (O-GlcNAcylation/ phosphorylation) pathways are either suppressed or activated.

\section{E. The $O$-GlcNAcylated Cytoskeleton}

The neuronal cytoskeleton is a composition of dynamic structural proteins important for cellular morphogenesis, organelle transport, and the regulation of neurotransmitter release $(22,23)$. Cytoskeletal elements also establish neuronal polarity and direct axoplasmic flow of synaptic vesicles to and from the synapse. The cytoskeleton consists of microtubules, intermediate filaments, including neurofilaments, microfilaments, and actin/membrane bridging proteins. Microtubules $(24 \mathrm{~nm})$ are polymers of $\alpha, \beta$ heterodimer subunits of tubulin, serve as rails for vesicle transport, and are required for the proper positioning of the mitotic spindle and nucleus in many cell types. Linking and bundling microtubules together are a family of proteins known as microtubule-associated proteins, MAPs. MAPs copurify with microtubules and also facilitate the polymerization of tubulin in vitro (24). The major MAPs in the brain include: MAP1, MAP2, and tau, all of which are multiply $O$ GlcNAcylated. The higher molecular weight MAPs including MAP1, MAP2, and MAP4 have approximate molecular weights of 350, 280, and (200-240) kDa respectively. MAP1 and MAP2 are exclusively found in neuronal tissue, whereas MAP4 is ubiquitously expressed and localizes to microtubules of mitotic and interphase cells. MAP2 is found predominately in dendrites, whereas MAP1 is localized in the cell body, dendrites, and axons of neurons.

\section{E-1. Glycosylation of Microtubule-Associated Proteins}

MAP1, MAP2, and MAP4 were all demonstrated to be glycosylated by the established method of periodate oxidation followed by detection with biotin hydrazide-streptavidin (25). $O$-GlcNAc was detected on MAP2 by probing for terminal $N$ acetylglucosamine residues with $\beta(1,4)$ GT and $\left[{ }^{3} \mathrm{H}\right]-\mathrm{UDP}-\mathrm{Gal}$ followed by gel fitration analysis of the $\beta$-eliminated radiolabeled sugars. Reverse-phase high pressure liquid chromatography (RP-HPLC) of radiolabeled MAP2 digested with trypsin
PMA すなわちプロテインキナーゼ C (PKC) 活性化因子、また はジブチリル cAMP、これはサイクリック-AMP 依存性プロテ インキナーゼ活性化因子 (PKA) である、のどれかで処理した 時、細胞骨格画分中のタンパク質 $O$-GlcNAc 化は、50-60\%程 度も減少した。逆に、ビス-インドールマレイミドによる PKCの 阻害は、細胞骨格 O-GlcNAc 化を 45 \% 増加させ, PKA の阻害 は、細胞骨格画分中で検出された O-GlcNAc の量を二倍にし た。従って、タンパク質リン酸化とO-GlcNAc 化は、細胞骨格 内で相反関係にあることが示された。驚いたことに、これらの 化合物による処理は、これらの研究で、細胞質ゾルや膜 $O$ GlcNAc 化にはほとんど影響しなかった。明らかに、これら二つ の翻訳後修飾の関係の複雑性は、(O-GlcNAc化/リン酸化) 経路 のどちらが抑制されるか、活性化されるかと同様に、どのタン パク質が修飾されるかにも依存している。

\section{E. O-GlcNAc化された細胞骨格}

神経細胞骨格は、細胞形態形成、細胞小器官輸送、神経伝 達物質放出の調節にとって重要でダイナミックな構造タンパク 質の混合物である(22、23)。細胞骨格要素はまた、ニューロン極 性を確立にし、シナプスへ向かい、またシナプスから来るシナ プス小胞の軸索原形質中の流れを支配する。細胞骨格は微小 管、ニューロフィラメントやミクロフィラメントを含んだ中間 フィラメント、アクチン/膜架橋タンパク質から構成される。微

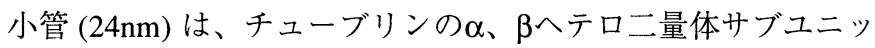
卜の重合体であり、小胞輸送のためのレールとして働き、多く の細胞型で有糸分裂紡鍾体と核が適切な位置を定めるために必 要とされている。微小管を架橋と束化するのは、微小管結合夕 ンパク質 MAPs として知られているタンパク質ファミリーであ る。MAPsは、微小管とともに精製され、また、in vitroにおい てチューブリンの重合を促進する (24)。脳中の主な MAPs は、 いずれも多数の $O$-GlcNAc 化を受ける MAP1、MAP2、夕ウを 含んでいる。MAP1、MAP2、およびMAP4を含むより高分子量 の MAP は、それぞれ 350、280、および(200-240) kDaである。

MAP1 とMAP2 はもっぱら神経組織中で見つけられるが、MAP4 はいたる所で発現し、有系分裂細胞と中間期細胞の微小管に局 在している。MAP2 は主として、樹状突起で見つけられるが、 MAP1 は細胞体、樹状突起、およびニューロンの軸索に局在し ている。

\section{E-1. 微小管関連タンパク質のグリコシル化}

MAP1、MAP2、およびMAP4 は、過ヨウ素酸酸化後ビオチ ンヒドラジドーストレプトアビジンで検出する方法によってすべ てグリコシル化されていることが示された。 MAP2 上の $O-$ GlcNAc 化は、 $\beta(1,4) G T$ と $\left[{ }^{3} \mathrm{H}\right]-U D P-G a l$ を用いて末端 $N$-アセチ ルグルコサミン残基を標識化し、その後、 $\beta$-脱離した放射能標 識糖鎖をゲルろ過分析にかけて検出された。放射能標識された MAP2をトリプシン消化して逆相高速液体クロマトグラフィー (RP-HPLC) にかけることによって、複数の部位が O-GlcNAc 化 
revealed three distinct peaks indicating multiple sites of $O$ GlcNAcylation. Further digestion of the polypeptide with thrombin indicated the presence of $O$-GlcNAc within the projection domain, a region which blocks abnormal MAP2 axonal transit and is required for proper dendritic targeting (48).

The lower molecular weight MAPs consist of a family of phosphoproteins known as tau which have molecular weights $(55-65 \mathrm{kDa})$ and are generated from the alternative splicing of a single gene (49). Tau regulates tubulin bundling and assembly, and stabilizes the microtubule network in the axons of neurons $(50,51)$. The phosphorylation of tau regulates its metabolism (52-54), its ability to bind and assemble microtubules $(55,56)$, and its tendency to self-associate (57). With some 17 (Ser/Thr)Pro regions, tau is a substrate for numerous protein kinases in vitro including: GSK3- $\beta(58,59)$, MAP kinase (erk2) (60), a neuronal cdc2 like protein kinase (61), CaMKII (62), casein kinase II (63), PKA $(64,65)$, and others $(66,67)$. However, it is still not clear which protein kinases are responsible for the regulation of tau phosphorylation in vivo.

$O$-GlcNAcylation of the low molecular weight family of tau proteins was detected both by blotting with succinylated wheat germ agglutinin, and by enzymatically probing with $\beta(1,4)$ GT and $\left[{ }^{3} \mathrm{H}\right]-U D P-G a l$. Structural analysis of the $\beta$-eliminated material was confirmed by high $\mathrm{pH}$ anion exchange chromatography (HPAEC-PAD). All tau splice variants are $O$-GlcNAcylated with an average stoichiometry of $\sim 4 \mathrm{~mol} \mathrm{GlcNAc/} \mathrm{mol} \mathrm{protein,}$ similar to the stoichiometry of tau phosphorylation. Tau is $O$ GlcNAcylated at 12 or more sites, suggesting substoichiometric site occupancy. It is unclear what role $O$-GlcNAcylation may have in tau function, but there are a host of possibilities. For instance, $O$-GlcNAc may modulate the phosphorylation state of tau by steric hinderance or direct reciprocity, which in turn would ultimately regulate all of the functions influenced by tau phosphorylation. These might include: regulating the binding and bundling of microtubules, controlling tau degradation, or even governing the localization of tau.

\section{E-2. Glycosylation of Intermediate Filaments}

Another family of proteins which contribute to the framework of the cytoskeleton are the intermediate filaments (IFs). IFs are highly dynamic structures composed of interwove $\alpha$-helical polypeptides that form coiled-coil dimer subunits creating an array of $10 \mathrm{~nm}$ filaments (68). There are five classes of IF proteins. IFs of class I and II are keratins which are broadly expressed in epithelial cells. Keratins K8, K13, and K18 give mechanical integrity to the stratified squamous epithelium. Single layer squamous epithelia predominately express $\mathrm{K} 8$ and $\mathrm{K} 18$ as obligate noncovalent heteropolymers $(\mathrm{K} 8 / \mathrm{K} 18)$, whereas $\mathrm{K} 13$ is found mostly in esophageal epithelia (69). Several post-translational modifications have been described for keratins including phosphorylation (70), acetylation (71), and $O$-GlcNAcylation (11).
されたことを示す、三つの別々のピークが示された。トロンビ ンによるポリペプチドのさらなる消化によって、異常な MAP2 軸索輸送を防ぎ適切な樹状突起への送達のために必要とされる 領域である突起ドメイン中の O-GlcNAc の存在が示された $(48)$ 。

より低分子量の MAP は、分子量 $(55-65 \mathrm{kDa})$ であり、一つ の遺伝子の選択的スプライシングによって生じる、タウとして 知られるリンタンパク質ファミリーから構成されている (49)。 タウは、チューブリン束化と集合を調節し、神経軸索中の微小 管ネットワークを安定化させる。タウのリン酸化は、その代謝 (52-54) や、微小管と結合し集合する能力 (55、66)、および自己 会合の傾向 (57) を調節する。タウは、in vitroにおいて、いく つかの 17 個の (Ser/Thr)-Pro 領域で、GK3- $\beta$ (58、59)、MAP キ ナーゼ (erk2) (60)、ニューロン cdc2 様プロテインキナーゼ (61)、 CaMKII (62)、カゼインキナーゼ II (63)、PKA (64、65)、および その他 $(66,67)$ を含む多数のプロテインキナーゼの基質にな る。しかしながら、どのプロテインキナーゼが、in vitroにおい てタウリン酸化の調節を行うのかは、まだ明らかではない。

タウタンパク質の低分子量ファミリーの O-GlcNAc 化は、 スクシニル化された小麦胚レクチンを用いるブロッティング、 および $\beta(1,4) \mathrm{GT}$ と $\left[{ }^{3} \mathrm{H}\right]-\mathrm{UDP}-\mathrm{Gal}$ で酵素的に標識することによっ

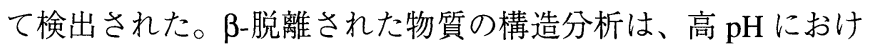
るアニオン交換クロマトグラフィー (HPAEC-PAD)によって確 認された。タウスプライス変異型すべてが、タウリン酸化の化 学量論と類似して、タンパク質 1 モル当り平均〜 4 モルの GlcNAcを含む化学量論で O-GlcNAc 化された。タウは 12 また はそれ以上の部位で O-GlcNAc 化を受け、ほぼ全ての部位が占 有されたことが示唆された。タウの機能において O-GlcNAc 化 が果たす役割は不明であるが、多数の可能性がある。例えば、 O-GlcNAc は、立体障害や直接の交換によって、タウのリン酸 化状態を調節し、その結果最終的にタウのリン酸化によって影 響される機能のすべてを調節する。これらは、微小管の結合と 束化の規制、夕ウの分解調節、または夕ウの局在支配さえ含ん でいるかもしれない。

\section{E-2. 中間フィラメントのグリコシル化}

細胞骨格の骨組に寄与する他のタンパク質ファミリーが、 中間フィラメント (IFs) である。IFs は、編み合わされた $\alpha$-へ リカルポリペプチドから成り立っていて、らせんがらせんに巻 き付いた二量体サブユニットを形成し、これが整列した $10 \mathrm{~nm}$ フィラメントを生じる(68)。IF タンパク質は5 クラスある。ク ラス I と II のIFsは広範囲に上皮細胞で発現されるケラチンで ある。ケラチン K8、K13、K18 は、層をなす鱗片状の上皮に機 械的完全性を与える。単一層の鱗片状上皮は主として、必然的 に非共有結合したへテロポリマー $(\mathrm{K} 8 / \mathrm{K} 18)$ として K8 と K18 を発現するが、K13 はほとんど食道上皮中に見出される (69)。 リン酸化 (70)、アセチル化 (71)、O-GlcNAc 化 (11) を含むいく つかの翻訳後修飾がケラチンについて述べられている。 
$O$-GlcNAc was first detected on keratins (K8/K18) by the established method of probing for terminal $N$ acetylglucosamine residues with $\beta(1,4) \mathrm{GT}$ in the presence of $\left[{ }^{3} \mathrm{H}\right]$ UDP-Gal, and analyzing the structure of the labeled sugars by $\beta$-elimination and thin layer chromatography. Keratins (K8/ K18) were demonstrated to contain $\sim(1.5-2)$ mol $O$-linked GlcNAc/ mol protein by chemical analysis. After digesting radiolabeled $\mathrm{K} 8$ and $\mathrm{K} 18$ with trypsin and elastase respectively, peptide mapping demonstrated the presence of multiple glycopeptides. As described previously, $O$-GlcNAc turnover on keratins $(\mathrm{K} 8 / \mathrm{K} 18)$ was shown to be much faster than polypeptide turnover. Additionally, cell cycle arrest caused a dramatic increase in the $O$-GlcNAcylation of threonine residues on $\mathrm{K} 18$, and an increase in the serine phosphorylation of $\mathrm{K} 8$, the obligate partner of K18 in filament assembly. Simultaneously with IF reorganization, keratin $O$-GlcNAcylation increased within head and proximal rod domains. However, mutational analysis suggests that $O$-GlcNAcylation is not required for keratin filament assembly (72). $O$-GlcNAcylation of keratins might nonetheless regulate keratin degradation, localization, or mediate IFprotein interactions.

Class IV IF proteins include neurofilaments NF-L, NF$\mathrm{H}$, and NF-M, the most abundant structural components in large myelinated axons. Neurofilaments assemble as obligate heteropolymers of NF-L (62 kDa), and either NF-H (115 kDa), or NF-M (100 kDa), and are essential for the development of axon diameter, a crucial factor in the velocity of nerve conduction (73). Each polypeptide shares a 310 amino acid $\alpha$-helical rod domain essential for the assembly of normal filaments, as well as a globular head domain, and variable length tail domain. Regions within both the $\mathrm{NH}_{2}$-terminal head and carboxyl-terminal domains are required for the proper networking of neurofilaments. All neurofilaments are post-translationally modified by phosphorylation. A majority of the sites of phosphorylation are located within the $\mathrm{C}$-terminal domains, albeit a small percentage also exist within the $\mathrm{NH}_{2}$-terminal head domains. Phosphorylation within the head domain of neurofilaments has been demonstrated to induce the disassembly of filaments (74), as well as inhibit filament assembly $(75,76)$. Neurofilaments are also $O$-GlcNAcylated within the head domains adjacent to sites of NF phosphorylation.

The $O$-GlcNAcylation of neurofilaments NF-H, NF-L, and NF-M purified from rat spinal cord was first identified by probing for terminal GlcNAc residues with $\beta(1,4) \mathrm{GT}$ in the presence of $\left[{ }^{3} \mathrm{H}\right]-\mathrm{UDP}-\mathrm{Gal}$, and analyzing the structure of the $\beta$-eliminated radiolabeled sugars by HPAEC-PAD. Purification of glycopeptides after proteolysis identified four major sites of glycosylation in the head domain of NF-L: Thr-21, Ser-27, Ser34, and Ser-48. Three out of four $O$-GlcNAcylation sites on NF-M were found in the head domain including Thr-19, Ser-34, and Thr- 48 , whereas the other, Thr- 431 , is located in the tail $\left[{ }^{3} \mathrm{H}\right]-$ UDP-Gal 存在下、 $\beta(1,4) \mathrm{GT}$ を用いて末端 $N$-アセチル グルコサミン残基を標識化し、 $\beta$-脱離と薄層クロマトグラ フィーによって標識された糖の構造を分析する確立された方法 によって、O-GlcNAc はケラチン (K8/K18) について初めて検出 された。ケラチン $(\mathrm{K} 8 / \mathrm{K} 18)$ は、化学分析によってタンパク質 1 モル当り〜(1.5-2) モルの O-GlcNAcを含むことが示された。放 射能標識された $\mathrm{K} 8 、 \mathrm{~K} 18$ をそれぞれトリプシン、エラスターゼ で消化した後、ペプチドマッピングによって、複数の糖ペプチ ドの存在を証明した。前に述べたように、ケラチン (K8/K18)で の O-GlcNAc 代謝回転は、ポリペプチド代謝回転よりずっと速 いことが示された。さらに、細胞周期の停止によって、K18で のトレオニン残基の $O$-GlcNAc が急激に増加し、フィラメント 集合において K18 の必須の相手である K8 のセリンリン酸化も 増加した。IF 再編成と同時に、ケラチン $O$-GlcNAc 化は、頭部 とこれに隣接した桿状体ドメイン中で増加した。しかしながら 突然変異分析によって、O-GlcNAc 化はケラチンフィラメント集 合に必要ないことが示された (72)。それでもなお、ケラチンの $O$-GlcNAc 化は、ケラチンの分解、局在、または IF-タンパク質 相互作用を調節しているかもしれない。

クラス IV の IF タンパク質は、ニューロフィラメント NFL、NF-H、およびNF-Mという大きな有髄軸索中の最も豊富な構 造成分を含んでいる。ニューロフィラメントは、NF-L (62kDa) と NF-H(115kDa)、または NF-M (100kDa) の必然的なへテロポ リマーとして集合し、神経伝達速度の重大な因子である軸索直 径の成長にとって必須である (73)。どのポリペプチドも、正常 な繊維形成に必要である 310 アミノ酸残基からなる $\alpha$-ヘリック ス桿状体ドメインを、球状頭部ドメインや可変長尾部ドメイン と同様に共有している。 $\mathrm{N}$-末端頭部ドメイン、C-末端ドメイン のどちらの領域も神経繊維の正常なネットワーキングに必要で ある。すべての神経繊維はリン酸化により翻訳後修飾をうけ る。N-末端頭部ドメインにも一部存在するものの、大部分のリ ン酸化部位は、C-末端ドメインに局在している。神経繊維の頭 部ドメインにおけるリン酸化によって、繊維の分解(74)が繊維形 成の阻害と同様に引き起こされることが証明された $(75 、 76)$ 。神 経繊維は、NFリン酸化部位に近隣した頭部ドメインで $O$ GlcNAc 化もうける。

ラットの脊䯣から精製された NF-H、NF-L や NF-M ど神 経繊維の $O-G I c N A c$ 化は、まず $\left[{ }^{3} \mathrm{H}\right]-\mathrm{UDP}-\mathrm{Gal}$ 存在下で $\beta(1,4) \mathrm{GT}$ を用いて末端 GlcNAc 残基を修飾し、さらに $\beta$-脱離して得た放 射能標識された糖鎖の構造を HPAEC-PAD で分析することによ り同定された。タンパク質分解後の糖ペプチドの精製から、NFL の頭部ドメインにある 4つの主なグリコシル化部位：Thr-21、 Ser-27、Ser-34、Ser-48 が確認された。NF-Mの O 型グリコシル 化の 4 つ部位のうち 3 つは Thr-19、Ser-34、Thr-48 を含む頭部 ドメインに見つけられている。一方、残りの Thr-431 は、尾部 領域に局在している。同様に、NF-H の O-グリコシル化は Thr- 
Trends in Glycoscience and Glycotechnology Vol.11 No.62 (November 1999) pp.355-370

region. The $O$-GlcNAcylation of NF-H likewise contains three sites of $O$-GlcNAc attachment in the head domain of the protein, including: Thr-53, Ser-54, and Ser-56. In addition, NF-H is multiply $O$-GlcNAcylated in the rod domain, a region consisting of 52 Lys-Ser-Pro repeats known to be highly phosphorylated. In accord with mutational studies, the presence of $O$ GlcNAc within the head domains has been proposed to regulate proper filament assembly. For instance, deletion of amino acids 18-30 from NF-L, including both $O$-GlcNAcylation sites Thr21 and Thr-27, caused a disruption of wild-type NF formation in transfected cells (77). Moreover, $\mathrm{NH}_{2}$-terminal deletion through the first site of $O$-GlcNAcylation on NF-M caused perinuclear aggregation instead of a proper formation of filament networks (78).

\section{E-3. O-GlcNAcylation of Actin-Membrane Bridging Pro- teins}

Another collection of $O$-GlcNAcylated cytoskeletal proteins tether the plasma membrane to the underlying network of spectrin-actin filaments. One of the first $O$-GlcNAcylated proteins identified, erythrocyte protein Band 4.1, or protein 4.1, is a member of this family. Band 4.1 is an $80 \mathrm{kDa}$ protein required for the formation of a spectrin-actin-4.1 ternary complex essential for the maintenance of proper red blood cell shape. $O$ GlcNAcylation of Band 4.1 has been demonstrated by $\beta(1,4) \mathrm{GT}$ labeling erythrocyte ghosts in the presence of $\left[{ }^{3} \mathrm{H}\right]-$ UDP-Gal. Chemical cleavage and digestion with $\alpha$-chymotrypsin has revealed that Band 4.1 is glycosylated within the carboxyl terminal 117 amino acids. Interestingly, mutations in this C-terminal region of the molecule, the actin-spectrin binding domain (79), can cause hereditary elliptocytosis resulting in hemolytic anemia (80). Moreover, Band 4.1 knockout mice have neurological defects in movement, coordination, balance and learning, in addition to hematological abnormalities (81). Related to Band 4.1 is a $215 \mathrm{kDa}$ cytoskeletal protein, talin, expressed in many different tissues. Talin is targeted to focal contacts (82), the postjunctional membrane of neuromuscular junctions (83), and interacts with vinculin and the cytoplasmic face of integrins (84). Talin purified from chicken gizzard and porcine stomach is modified with $O$-GlcNAc (32). Two glycosylation sites were identified and are located in the tail domain. $O$-GlcNAcylation of this region may play a role in regulating talin's interaction with vinculin, another $O$-GlcNAcylated protein, or other cytoskeletal proteins.

Recently, ankyrin ${ }_{\mathrm{G}}$ was also identified as another $O$ GlcNAcylated protein which bridges the membrane to the spectrin-actin network. Ankyrin ${ }_{\mathrm{G}}$ is targeted to Nodes of Ranvier, regions within myelinated axons where ion fluxes of action potentials are propagated (85). Ankyrin ${ }_{\mathrm{G}}$ is essential for the proper localization of voltage-dependent sodium channels, and for normal firing in Purkinje neurons (86). Ankyrins also bind the cytoplasmic domains of a family of immunoglobulin/
53、Ser-54、Ser-56 を含むタンパク質の頭部ドメインに、OGlcNAc 結合の 3 つの部位を含んでいる。さらに加えて、NF-H は高度にリン酸化を受けることで知られる Lys-Ser-Pro の 52 回 のくり返しから成る領域である桿状ドメインで多数のリン酸化 をうける。変異体実験と一致して、頭部ドメインにおける $O$ GlcNAc の存在は、適切な繊維形成を調節することが提案され た。例えば、NF-L から O-GlcNAc 化部位である Thr-21 と Thr27 を含む $18 \sim 30$ のアミノ酸残基を除去すると、形質転換さ れた細胞での野生型の NF 形成の阻害がおこる(77)。さらに、

NF-M の第一の O-GlcNAc 化部位の N-末端の除去により、正常 な繊維ネットワークの形成の代わりに核周辺での凝集がおこる (78)。

\section{E-3. アクチン-膜架橋タンパク質のO-GlcNAc化}

O-GlcNAc 化をうけた細胞骨格タンパク質の他の集合は、ス ペクトリン-アクチン繊維の内在するネットワークに形質膜をつ なぐ。初めに同定された O-GlcNAc 化タンパク質の1つである 赤血球タンパク質 Band 4.1、またはタンパク質 4.1 はこのファ ミリーの 1 つである。Band 4.1 は赤血球を正しい形に保つのに 必須な、スペクトリン-アクチン-4.1の三者複合体形成に必要な $80 \mathrm{kDa}$ のタンパク質である。Band 4.1 の O-GlcNAc 化は、[ $\left.{ }^{3} \mathrm{H}\right]-$ UDP-Gal 存在下で赤血球ゴーストを $\beta(1,4) \mathrm{GT}$ 標識することによ り証明された。化学的切断や $\alpha$-キモトリプシンによる分解によ り、Band 4.1 はC-末端の 117 アミノ酸残基内でグリコシル化を 受けることが明かとなってきた。興味深いことに、分子中のC末端領域、アクチン-スペクトリン結合ドメイン(79)に突然変異 が加わると、遺伝性のだ円赤血球症を引き起こし、その結果溶 血性負血となる(80)。さらに、Band 4.1 ノックアウトマウスは血 液学的異常に加えて運動、筋肉運動の協同、バランスや学習に おいて神経学的欠陥をもっている(81)。Band 4.1 に関連して、さ まざまな組織で発現される $215 \mathrm{kDa}$ の細胞骨格タンパク質であ るテーリンがある。テーリンは神経筋結合の接合後の膜状態(83) である巣状接着に送達され(82)、ビンキュリンやインテグリンの 細胞質側と相互作用する(84)。ニワトリの砂囊とブタの胃から精 製されたテーリンは O-GIcNAcで修飾されている(32)。2つのグ リコシル化部位が同定され、それらは尾部ドメインに局在して いる。この領域での O-GlcNAc 化は、テーリンのビンキュリ ン、他の O-GlcNAc 化をうけたタンパク質または他の細胞骨格 タンパク質との相互作用を調節するのに何らかの役割をはたし ているだろう。

最近、アンキリン $\mathrm{G}$ が、膜をスペクトリン-アクチンネッ トワークに架橋するもう一つの O-GlcNAc 化タンパク質として 同定された。アンキリン $\mathrm{G}$ は活動電位のイオン流量が伝達され る有䯣軸索内の領域であるランビエ絞輪に送達される(85)。アン キリン $\mathrm{G}$ は電位依存的 $\mathrm{Na}^{+}$チャンネルの正しい局在やプルキン エニューロンの正常な発火に必須である(86)。アンキリンは ニューロファシン、NrCAM、L1、NgCAM を含む免疫グロブリ 
fibronectin type III cell adhesion molecules including: neurofascin, NrCAM, L1, and NgCAM (87). Due to the presence of a $40 \mathrm{kDa}$ Ser/Thr rich domain unique to $\operatorname{ankyrin}_{\mathrm{G}}(85)$, its glycosylation was investigated.

$480 \mathrm{kDa}$ ankyrin $_{\mathrm{G}}$ extracted from brain membranes bound wheat germ agglutinin affinity columns, was labeled by $\beta(1$, 4)GT and $\left[{ }^{3} \mathrm{H}\right]-U D P-G a l$, and cross-reacted with an $O$-GlcNAc specific antibody (29). The nodal mucin-like Ser/Thr rich domain was determined to be $O$-GlcNAcylated, and mutational analysis indicated this region contributes to the prevention of the lateral diffusion of ankyrin-neurofascin complexes (88).

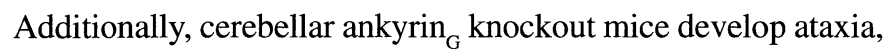
sodium-channel mistargeting and progressive Purkinje neuron degeneration (86). Thus, $O$-GlcNAc may modulate the proper development and arrangement of protein-ankyrin complexes at the Nodes of Ranvier required for normal firing in Purkinje cells.

Nerve terminals also contain cytoskeletal membrane bridging proteins. There exists a mechanism that requires vesicle targeting and membrane fusion within neurons for the proficient uptake and release of neurotransmitters. This process of synaptic transmission involves the rapid recycling of synaptic vesicles at the synapse. Concentrated within the nerve terminal are cytoskeleton bridging proteins known as synapsins. Synapsin I sequesters fusion competent vesicles by anchoring them to the proximal cytoskeletal network in a phosphorylation dependent manner (89). Synapsin I is also multiply $O$-GlcNAcylated near neighboring phosphorylation sites within domains dedicated to binding synaptic vesicles (90), and domains required for binding (91), and nucleating (92) actin. Seven $O$-GlcNAcylation sites have been identified on synapsin I using a combination of RP-HPLC, electrospray mass spectrometry (ES-MS), and matrix assisted laser desorption ionization time of flight (MALDI TOF) mass spectrometry (34). The localization of $O$-GlcNAc residues within these domains suggests that $O$-GlcNAcylation of synapsin I may modulate directly, or by regulating synapsin I phosphorylation, its ability to bind and anchor synaptic vesicles to the actin cytoskeleton.

The mechanism of synaptic vesicle re-uptake is considered similar to clathrin-coated pit mediated endocytosis, an internalization process common to all cells. Important for the assembly of clathrin-coated vesicles (93), as well as for synaptic vesicle recycling $(94,95)$, is the $160 \mathrm{kDa}$ clathrin-assembly protein AP3. $O$-GlcNAcylation of AP3 was demonstrated when peptide $N$-glycosidase F (PNGase F) treated human brain homogenates were probed with $\beta(1,4) \mathrm{GT}$ and $\left[{ }^{3} \mathrm{H}\right]-\mathrm{UDP}-\mathrm{Gal}$, and a radiolabeled $160 \mathrm{kDa}$ AP3 immunoreactive band with the appropriate corresponding isoelectric point was identified (36). Since bacterially expressed AP3 is capable of clathrin binding and assembly (96), and in vitro galactosylated AP3 is clathrin assembly competent (97), it is unclear how $O$-GlcNAc affects the function of AP3. However, since both Synapsin I and clathrin
ン/フィブロネクチンタイプ III 細胞接着分子ファミリーの細胞 質ドメインにも結合する(87)。40 kDa の Ser/Thrに富んだドメ インがアンキリン $\mathrm{G}$ に特有であることから(85)そのグリコシル 化について調べられた。

コムギ胚芽凝集素アフィニティーカラムに結合した脳膜か ら抽出された $480 \mathrm{kDa}$ のアンキリン $\mathrm{G}$ を $\beta(1,4) \mathrm{GT}$ と $\left[{ }^{3} \mathrm{H}\right]$-UDPGal で標識し、O-GlcNAc 特異的抗体を用いて交差反応を行なっ た(29)。節のムチン様 Ser/Thr の豊富なドメインは O-GlcNAc 化 されていると決定され、突然変異分析により、この領域がアン キリン-ニューロファシン複合体の側方拡散の妨害に寄与するこ とがわかった(88)。加えて、小脳アンキリン Gノックアウトマ ウスは機能障害、 $\mathrm{Na}^{+}$チャンネルの誤ターゲティング、および進 行性のプルンキエニューロンの変性退化を発病する(86)。それゆ え、O-GlcNAc はプルンキエ細胞での正常な焼成に必要となるラ ンビエ絞輪での夕ンパク質-アンキリン複合体の適切な発達や配 置の調節を行っていると考えられる。

神経終末も同様に、細胞骨格膜架橋タンパク質を含んでい る。神経伝達物質をうまく摄取し、また放出するためにニュー ロン内での小胞のターゲティングと膜融合を必要とするメカニ ズムが存在する。シナプス伝達のこのプロセスには、シナプス において、シナプス小胞の迅速な再生が含まれる。神経終末内 には、シナプシンとして知られている細胞骨格架橋タンパク質 が濃縮されている。シナプシンIは、融合可能な小胞をリン酸 化依存的に中央に近い細胞骨格ネットワークにつなぎ止めるこ とで隔離する(89)。シナプシンIは、シナプス小胞との結合ドメ インや(90)、アクチン結合(91)扔よびアクチン核化に必要とされ るドメイン(92)内のリン酸化部位の近くで多数の O-GlcNAc 化も 受ける。RP-HPLC、電子スプレー質量分析計（ES-MS）と、マ トリックス介助レーザーデソープションイオン化飛行時間型質 量分析計 (MALDI-TOF) の組み合わせを用いてシナプシン Iに は、7つの O-GlcNAc 化部位が同定された(34)。これらドメイン 内での O-GlcNAc 残基の局在により、シナプシン I の O-GlcNAc 化が直接的に、またはリン酸化を調節することで、シナプシン Iのシナプス小胞をアクチン細胞骨格へと結合させ固定化する能 力を調節するものと考えられる。

シナプス小胞再吸収のメカニズムはすべての細胞に共通の 吸収のプロセスである、クラスリン被覆孔によるエンドサイ トーシスに似ているものと考えられている。160kDaのクラスリ ン-会合タンパク質 AP3 が、シナプス小胞の再生(94、95) と同様 にクラスリン被覆小胞(93)の会合に重要である。AP3 の $O-$ GlcNAc 化は、ペプチド $N$-グリコシダーゼF (PNGaseF) で処理 されたヒト脳懸濁液を $\beta(1,4) \mathrm{GT}$ と $\left.{ }^{3} \mathrm{H}\right]-\mathrm{UDP}-\mathrm{Gal}$ で標識し、放 射能標識された $160 \mathrm{KDa} \mathrm{AP} 3$ に相当する等電点を示す免疫反応 性バンドが同定された時に証明された(36)。細菌により発現され たAP3 はクラスリンと結合、および集合することができ(96)、 in vitro でガラクトシル化された AP3 もクラスリンを集合させ る能力を持つことから(97)、AP3 の機能に O-GlcNAc がどのよ 
AP3 are enriched at the synapse, $O$-GlcNAcylation may play a role in maintaining their localization. $O$-GlcNAc might also regulate the dynamic recycling of vesicles to and from the membrane.

\section{F. Neurodegenerative Diseases Involving $\boldsymbol{O}$-GlcNAcylated}

\section{Cytoskeletal Proteins}

Neurodegenerative diseases encompass a large number of disorders. Yet, many have a common etiology that is characterized by the formation of filamentous lesions composed of highly phosphorylated cytoskeletal proteins. Alzheimer's disease (AD), for example, is a progressive neurodegenerative disease which has a distinct pathology (98). Two neuropathological hallmarks found in AD brains are neurofibrillary tangles (NFTs) composed of paired helical filaments (PHFs) (99), and amyloid plaques composed of peptides generated from the abnormal processing of the $\beta$-amyloid precursor protein ( $\beta$-APP) $(100-102)$. Biochemical characterization of PHFs has determined that they are composed primarily of abnormally hyperphosphorylated tau protein (PHF-Tau) (103-106). NFTs are also found in a multitude of other neurodegenerative disorders including: frontotemporal dementia and Parkinsonism linked to chromosome 17 (FTDP-17), Pick's disease, progressive supranuclear palsy, and others (107) (Table II). The presence of NFTs in many pathologies, and its correlation with cognitive impairment $(108,109)$, indicate that the abnormal hyperphosphorylation of tau is a central event in neuron death. Deciphering the mechanism of hyperphosphorylated tau formation, therefore, is crucial to our understanding of the etiology of neurodegeneration.

Since their enzymatic activities are diminished in Alzheimer brains (110), a possible mechanism may include al-
うに影響するのか、ということは今だ明かとなっていない。し かしながら、シナプシン I と、クラスリン AP3がどちらもシナ プスに多く存在することから、O-GlcNAc 化はそれらの局在維持 に何らかの役割を持つものと考えられる。加えて、AP3 の $O-$ GlcNAc 化は、クラスリン被覆集合と小胞再吸収の動力学にも何 らかの役割を持つかもしれない。

\section{F. O-GIcNAc化細胞骨格タンパク質に関連した神経変性疾患}

神経変性疾患は数多くの障害をもたらす。しかし、その多 くは高度にリン酸化を受けた細胞骨格タンパク質からなる繊維 病巣の形成に特徽づけられる共通の病因をもっている。例え ば、アルツハイマー病 (AD) は、異った病状を示す進行性の神経

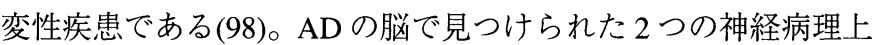
の特徵は、ヘリックス対繊維 (PHFs) (99)から成る神経瀻維のも つれ (NFTs) と、 $\beta$-アミロイド前駆体タンパク質 ( $\beta$-APP) の異常 なプロセシングにより生じるぺプチドから成るアミロイドプ ラークである(100-102)。PHFs の生化学的特徵づけにより、それ らが異常に過度なリン酸化をうけたタウタンパク質(PHF-Tau)に より主に形成されていることが決定された(103-106)。NFTsは 同様に前頭葉側頭部麻痺や染色体 17 (FTDP-17) に関連したパー キンソン病、ピック病や進行性核上麻瘏など(107)他の多くの神 経変性疾患でも見受けられる(表II)。多くの病変での、NFTsの存 在や知覚損傷との相互関係により $(108 、 109)$ 夕ウタンパク質の異 常な過度のリン酸化はニューロン死の中心的な出来事であるこ とが示された。それゆえ、過度なリン酸化をうけたタウタンパ ク質が形成されるメカニズムの解明が、神経変性の病因を解釈 するのに必須なのである。

アルツハイマー脳で、タンパク質ホスファターゼ PP2A と PP2B の酵素的活性が減少することから(110)、タウタンパク質に

Table II. Examples of the numerous neurodegenerative diseases in which the microtubule associated protein tau is involved.

\title{
Neurodegenerative Diseases with Abundant Tau Filamentous Lesions
}

\author{
Alzheimer's disease \\ Down's syndrome \\ Corticobasal Degeneration \\ Dementia pugilistica \\ Dementia with tangles \\ Frontotemporal dementias \\ Parkinsonism linked to chrom. 17 \\ Myotonic dystrophy \\ Niemann-Pick disease type $C$ \\ Parkinsonism-dementia complex of Guam \\ Pick's disease \\ Postencephalitic Parkinsonism \\ Prion diseases with tangles \\ Progressive supranuclear palsy \\ Subacute sclerosing panencephalitis
}


Fig. 3. Tau $\boldsymbol{O}$-GIcNAcylation and Alzheimer's Disease. A model depicting the outcome of defective tau $O$-GlcNAcylation on neurofibrillary tangle formation, and ultimately neuron death.

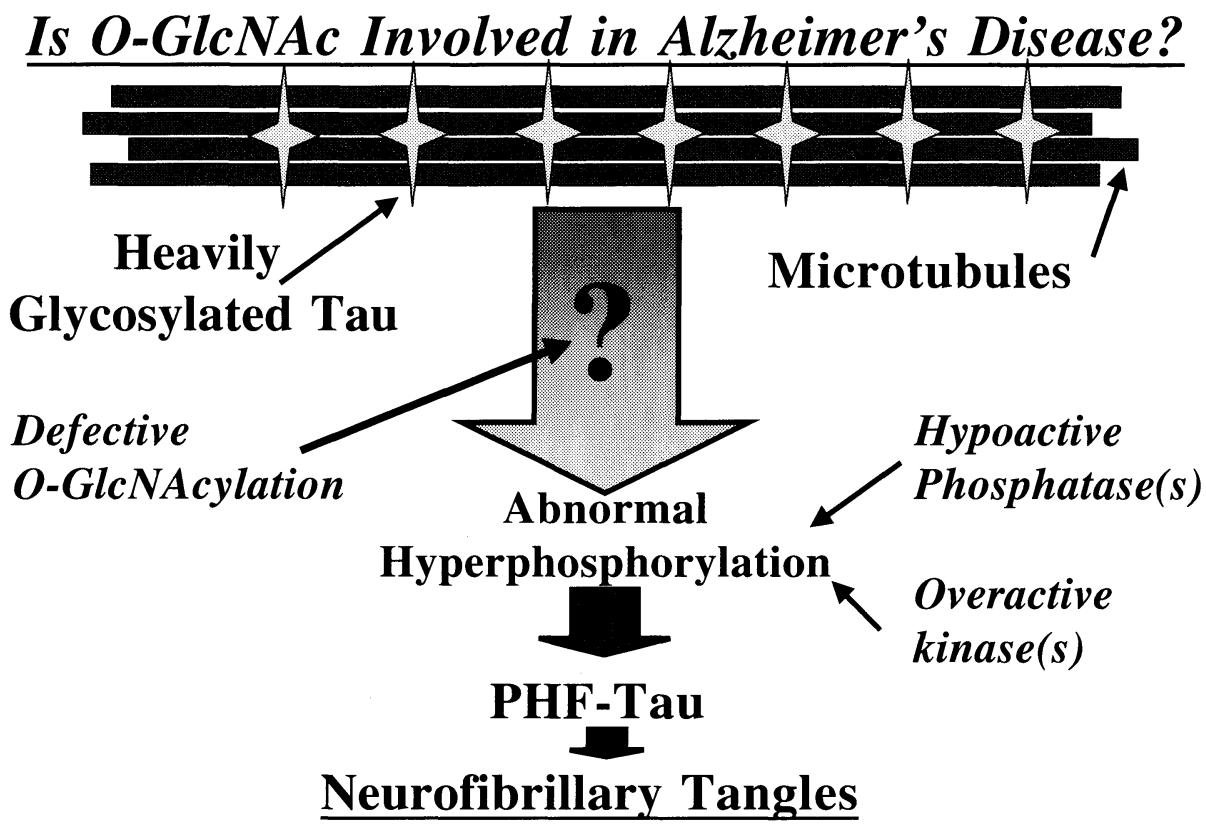

terations in protein phosphatases PP2A and PP2B activities toward tau. Another scenario could include the activation of protein kinase pathways. PHF-Tau isolated from AD brains is phosphorylated on at least twenty-five sites (111). Tau is a substrate for protein kinases in vitro including : GSK-3 $\beta$, p34cdc2, CaMKII, PKA, MAP kinase, and numerous others. The concerted activation of multiple phosphorylation pathways would likely be required in order to achieve the extraordinary phosphorylation state of tau found in NFTs. Regardless, these kinases phosphorylate a majority, but not all of the sites identified in tau from $\mathrm{AD}$ brain $(112,113)$. However, due to the fact glucose metabolism is significantly impaired in Alzheimer brains $(114,115)$, and UDP- $N$-acetylhexosamine biosynthesis is sensitive to the availability of glucose (116), a drastic reduction in UDP-GlcNAc levels would be eminent. This could ultimately reduce the $O-G 1 c N A c y l a t i o n$ of proteins AD brain. Such an observation has already been documented for the cytoskeletal protein AP3 $(36,37)$. Reduced tau $O$-GlcNAcylation might therefore ultimately unmask potential phosphorylation sites unique to $\mathrm{AD}$ brain and result in NFT formation.

\section{G. Summary}

The nervous system is a rich source of filamentous proteins critical in maintaining proper neuronal morphology and function. Numerous cytoskeletal proteins have been shown to be modified by $O$-GlcNAc and are involved in the pathogenesis of neurodegenerative diseases such as Alzheimer's. The highly phosphorylated forms tend to precipitate as insoluble filamentous inclusions (NFTs) which leads to blocked axonal transport,
対するそれらの活性変化を含むメカニズムが考えられる。プロ テインキナーゼ経路の活性化を含む、別のシナリオも考えられ る。 $\mathrm{AD}$ 脳から得られた PHF-タウタンパク質は、少なくとも 25 の部位でリン酸化をうける(111)。夕ウは、in vitro で GSK-3ß、 p34cdc2、CaMKII、PKA、MAPキナーゼなど多くのプロテイン キナーゼの基質となる。複数のリン酸化経路の協調した活性化 は、NFTs で見られるタウタンパク質の異常なリン酸化状態を達 成するのに必要らしく思われる。それとは関係なく、これらキ ナーゼは $\mathrm{AD}$ 脳から得られたタウタンパク質において同定され た部位の大半をリン酸化するが、すべての部位ではない(112、 113)。しかしながら、アルツハイマー脳でグルコース代謝が激 減し(114、115)、かつ UDP-N-アセチルヘキソサミンの生合成は グルコースが得られるかどうかによって影響をうけやすい(116) という事実から、UDP-GlcNAc 量の激減は著しいことだろう。 これは、結果的に AD 脳のタンパク質 $O$-GlcNAc 化を減少する ことになる。このような観察はすでに、細胞骨格タンパク質 AP3 でなされている(36、37)。よって、タウタンパク質の $O$ GlcNAc 化の減少は、AD 脳特有な潜在的リン酸化部位を露出 し、その結果 NFT を形成する。

\section{G. 結 論}

神経システムは、正確な神経の形態と機能の維持に必須な 繊維状タンパク質に富んだ源である。多数の骨格タンパク質 は、O-GlcNAcによる修飾をうけ、アルツハイマーなどの神経変 性疾患の発病に必要であることが示された。高度にリン酸化さ れた型は、不溶性の繊維状封入物(NFTs)として沈澱する傾向が あり、軸索輸送の妨害、神経伝達物質の吸収と放出の阻害を導 
Trends in Glycoscience and Glycotechnology Vol.11 No.62 (November 1999) pp.355-370

inhibition of neurotransmitter uptake and release, and ultimately massive neuron death. The reciprocal relationship between $O$ GlcNAcylation, and $O$-phosphorylation may ultimately be a causative link in the mechanism of pathogenesis for several neurodegenerative disorders.
き、最後は大規模なニューロン死をもたらす。O-GlcNAc 化と O-リン酸化の相反関係が、いくつかの神経性疾患の発病メカニ ズムにおいて究極の原因となる繋がりかもしれない。

扮茶の水女子大学理学部化学科

鈴木 理沙、浅沼 公恵、田中 亮子 共訳

\section{References}

1. Hart, G. W., Kreppel, L.K., Comer, F. I., Arnold, C. S., Snow, D. M., Ye, Z., Cheng, X., DellaManna, D., Caine, D. S., Earles, B. J., Akimoto, Y., Cole, R. N., and Hayes, B.K. (1996) Glycobiology 6, 711-716

2. Snow, D. M., and Hart, G. W. (1998) Internat. Rev. of Cytology 181, 43-74

3. Hayes, B. K., and Hart, G. W. (1994) Curr. Opin. Struct. Biol. 4, 692-696

4. Hart, G. W. (1997) Annu. Rev. Biochem. 66, 315-335

5. Hart, G. W., Greis, K. D., Dong, D. L.-Y., Blomberg, M. A., Chou, T.-Y., Jiang, M. S., Roquemore, E. P., Snow, D. M., Kreppel, L. K., Cole, R. N., and Hayes, B. K. (1995) Pure Appl. Chem. 67, 1637-1645

6. Haltiwanger, R. S., Kelly, W. G., Roquemore, E. P., Blomberg, M. A., Dong, D. L. Y., Kreppel, L. K., Chou, T.-Y., and Hart, G. W. (1992) Biochem. Soc. Trans. 20, 264-269

7. Roquemore, E. P., Chevrier, M. R., Cotter, R. J., and Hart, G. W. (1996) Biochem. 35, 3578-3586

8. Chou, C.-F., Smith, A. J., and Omary, M. B. (1992) J. Biol. Chem. 267, 3901-3906

9. Kearse, K. P., and Hart, G. W. (1991) Proc. Natl. Acad. Sci. USA 88, 1701-1705

10. Haltiwanger, R. S., Grove, K., and Phillipsberg, G. A. (1998) J. Biol. Chem. 273, 3611-3617

11. Chou, C.-F., and Omary, M. B. (1993) J. Biol. Chem. 268, 4465-4472

12. Holt, G. D., and Hart, G. W. (1986) J. Biol. Chem. 261, 8049-8057

13. Kelly, W. G., Dahmus, M. E., and Hart, G. W. (1993) J. Biol. Chem. 268, 10416-10424

14. Holt, G. D., Snow, C. M., Senior, A., Haltiwanger, R. S., Gerace, L., and Hart, G. W. (1987) J. Cell. Biol. 104, 1157-1164

15. Starr, C. M., and Hanover, J. A. (1990) J. Biol. Chem. 265, 6868-6873

16. Shaw, P., Freeman, J., Bovey, R., and Iggo, R. (1996) Oncogene 12, 921-930

17. Chou, T.-Y., Dang, C. V., and Hart, G. W. (1995) Proc. Natl. Acad. Sci. USA 92, 4417-4424

18. Privalsky, M. L. (1990) J. Virol. 64, 463-466

19. Jiang, M.-S., and Hart, G. W. (1997) J. Biol. Chem. 272, 2421-2428

20. Medina-Vera, L., and Haltiwanger, R. S. (1994) Mol. Biol. Cell 5(S), 340a

21. Matus, A. (1988) Ann. Rev. Neurosci. 11, 29-44

22. Hirokawa, N. (1994) Curr. Opin. Cell Biol. 6, 74-81

23. Hirokawa, N. (1993) Neuronal Cytoskeleton: Morphogenesis, Transport and Synaptic Transmission: Japan Scientific Societies Press.

24. Cleveland, D. W., Hwo, S.-Y., and Kirschner, M. W. (1977) J. Mol. Biol. 116, 207-225

25. Ding, M., and Vandre, D.D. (1996) J. Biol. Chem. 271, 12555-12561

26. Arnold, C. S., Johnson, G.V.W., Cole, R.N., Dong, D.L.-Y., Lee, M., and Hart, G. W. (271) J. Biol. Chem. 271, 28741-28744

27. Dong, D. Y.-L., Xu, Z.-S., Chevrier, M. R., Cotter, R. J., Cleveland, D.W., and Hart, G.W. (1993) J. Biol. Chem. 268, 16679-16687

28. Dong, D. Y.-L., Xu, Z.-S., Hart, G.W., and Cleveland, D.W. (1996) J. Biol. Chem. 271, 20845-20852

29. Zhang, X., and Bennett, V. (1996) J. Biol. Chem. 271, 31391-31398

30. Roquemore, E. P., Dell, A., Morris, H. R., Panico, M., Reason, A. J., Savoy, L.-A., Wistow, G. J., Zigler, S. Jr., Earles, B. J., and Hart, G. W. (1992) J. Biol. Chem. 267, 555-563

31. Holt, G. D., Haltiwanger, R. S., Torres, C.-R., and Hart, G. W. (1987) J. Biol. Chem. 262, 14847-14850

32. Hagmann, J., Grob, M., and Burger, M. M. (1992) J. Biol. Chem. 267, 14424-14428

33. Vostal, J. G., and Kransnewich, D. M. (1996) Mol. Biol. Cell 5(S), 263a

34. Cole. R. N., and Hart, G.W. (1999) J. Neurochem. 73, 418-428

35. Murphy, J.E., Hanover, J.A., Froelich, M., Dubois, G., and Keen, J. H. (1994) J. Biol Chem. 269, 21346-21352

36. Yao, P.J., and Coleman, P.D. (1998) J. Neurosci. 18, 2399-2411

37. Yao, P.J., and Coleman, P.D. (1998) Neurosci. Lett. 252, 33-36

38. Haltiwanger, R. S., Blomberg, M.A., and Hart, G.W. (1992) J. Biol. Chem. 267, 9005-9013

39. Kreppel, L.K., Blomberg, M.A., and Hart, G.W. (1997) J. Biol. Chem. 272, 9308-9315

40. Lubas, W. A., Frank, D. W., Krause, M., and Hanover, J.A. (1997) J. Biol. Chem. 272, 9316-9324

41. Dong, D, L.-Y., and Hart, G.W. (1994) J. Biol. Chem. 269, 19321-19330

42. Kreppel, L. K., and Hart, G.W. (1999) J. Biol. Chem. 274, 32015-32022

43. Lamb, J. R., Tuggendreich, S., and Hieter, P. (1995) Trends. Biochem. Sci. 20, 257-259

44. Reason, A.J., Morris, H.R., Panico, M., Marais, R., Treisman, R.H., Haltiwanger, R.S., and Hart, G.W. (1992) J. Biol. Chem. 267, 1691116921

45. Chou, C.-F., and Omary, M. B. (1994) J. Cell Sci. 107, 1833-1843

46. Chou, T.-Y., Hart, G. W., and Dang, C.V. (1995) J. Biol. Chem. 270, 18961-18965B

47. Griffith, L. S., and Schmitz, B. (1999) Eur. J. Biochem. 262, 824-831

48. Kanai, Y., and Hirokawa, N. (1995) Neuron 14, 421-432

49. Goedert, M., Spillaantini, M. G., Jakes, R., Rutherford, D., and Crowther, R.A. (1989) Neuron 3, 519-526 
Trends in Glycoscience and Glycotechnology Vol.11 No.62 (November 1999) pp.355-370

50. Drubin, D. G., and Kirschner, M. W. (1986) J. Cell Biol. 103, 2739-2746

51. Lee, G. (1990) Cell Motil. Cytoskel. 15, 199-203

52. Litersky, J. M., and Johnson, G. V. W. (1995) J. Neurochem. 65, 903-911

53. Mercken, M., Grynsan, F., and Nixon, R. A. (1995) FEBS Lett. 368, 10-14

54. Preuss, U., Doring, F., Illenberger, S., and Mandelkow, E.-M. (1995) Mol. Biol. Cell 6, 1397-1410

55. Bramblett, G. T., Goedert, M., Jakes, R., Merrick, S. E., Trojanowski, J. Q., and Lee, V. M. (1993) Neuron 10, 1089-1099

56. Ikbal, K., Zaidi, T., Bancher, C., and Grundke-Ikbal, I. (1994) FEBS Lett. 349, 104-108

57. Paudel, H. K. (1997) J. Biol. Chem. 272, 28328-28334

58. Hanger, D. P., Hughes, K., Woodgett, J. R., Brion, J. P., and Anderton, B. H. (1992) Neurosci. Lett. 147, 58-62

59. Mandelkow, E. M., Drewes, G., Biernat, J., Gustke, N., Van Lint, J., Vandenheede, J. R., and Mandelkow, E. (1992) FEBS Lett. 314, $315-321$

60. Drewes, G., Lichtenberg-Kraag, B., Doring, F., Mandelkow, E. M., Biernat, J., Goris, J., Doree, M., and Mandelkow, E. (1992) EMBO J 11, 2131-2138

61. Paudel, H. K., Lew, J., Ali, Z., and Wang, J. H. (1993) J. Biol. Chem. 268, 23512-23518

62. Steiner, B., Mandelkow, E. M., Biernat, J., Gustke, N., Meyer, H. E., Schmidt, B., Mieskes, G., Soling, H. D., Dreschel, D., and Kirschner, M. W. (1990) EMBO J 9, 3539-3544

63. Greenwood, J. A., and Johnson, G.V.W. (1994) J. Biol. Chem. 269, 4373-4380

64. Pierre, M., and Nunez, J. (1983) Biochem. Biophys. Res. Comm. 115, 212-219

65. Litersky, J. M., and Johnson, G.V.W. (1992) J. Biol. Chem. 267, 1563-1568

66. Drewes, G., Trinczek, B., Illenberger, S., Biernat, J., Schmitt-Ulms, G. Meyer, H. E., Mandelkow, E.M., and Mandelkow, E. (1995) J. Biol. Chem. 270, 7679-7688

67. Paudel, H. K. (1997) J. Biol. Chem. 272, 1777-1785

68. Fuchs, E. (1996) Annu. Rev. Genet. 30, 197-231

69. Franke, W. W., Schieller, D. L., Moll, R., Winter, S., Schmid, E., Engelbrecht, I., Denk, H., Krepler, R., Platzer, B. (1981) J. Mol. Biol. 153, 933-959

70. Gilmartin, M. E., Mitchell, J., Vidrich, A., and Freedberg, I. M. (1984) J. Cell. Biol. 98, 1144-1148

71. Steinert, P. M., and Idler, W.W. (1975) Biochem. J. 151, 603-614

72. Ku, N-O., and Omary, M., B. (1995) J. Biol. Chem. 270, 11820-11827

73. Lee, M. K., and Cleveland, D. W. (1996) Annu. Rev. Neurosci. 19, 187-217

74. Chou, C.H., Rosevear, E., and Goldman, R.D. (1990) Proc. Natl. Acad. Sci. USA 86, 1885-1889

75. Hisanaga, S., Gonda, Y., Inagaki, M., Ikai, A., and Hirokawa, N. (1990) Cell Regul. 1, 237-248

76. Hisanaga, S., Matsuoka, Y., Nishizawa, K., Saito, T., Inagaki, M., et al. (1994) J. Neurochem. 63, 387-389

77. Gill, S. R., Wong, P. C., Monteiro, M. J., and Cleveland, D.W. (1990) J. Cell Biol. 111, 2005-2019

78. Wong, P. C., and Cleveland, D. W. (1990) J. Cell Biol. 111, 1987-2003

79. Correas, I., Leto, T. L., Speicher, D. W., and Marchesi, V. T. (1986) J. Biol. Chem. 261, 3310-3315

80. Delaunay, J. (1995) Crit. Rev. Oncol. Hematol. 19, 79-110

81. Walensky, L. D., Shi, Z. T., Blackshaw, S., DeVries, A. C., Demas, G. E., Gascard, P., Nelson, R. J., Conboy, J. G., Rubin, E. M., Snyder, S. H., and Mohandas, N. (1998) Curr. Biol. 8, 1269-1272

82. Burridge, K., and Connell, K. L. (1983) J. Cell Biol. 97, 359-367

83. Sealock, R., Paschal, B., Beckerle, M. C., and Burridge, K. (1986) Exp. Cell Res. 163, 143-150

84. Horowitz, A., Duggan, K., Buck, C., Beckerle, M. C., and Burridge, K. (1986) Nature 320, 531-533

85. Kordeli, E., Lambert, S., and Bennett, V. (1995) J. Biol. Chem. 270, 2352-2359

86. Zhou, X., Lambert, S., Malen, P. L., Carpenter, S., Boland, L. M., and Bennett, V. (1998) J. Cell Biol. 143, 1295-1304

87. Davis, J. Q., Lambert, S., and Bennett, V. (1996) J. Cell Biol. 135, 1355-1367

88. Zhang, X., and Bennett, V. (1998) J. Cell Biol. 142, 1571-1581

89. Greengard, P., Benfenati, F., and Valtorta, F. (1994) Adv. Sec. Messenger Phosphoprot. Res. 29, 31-45

90. Schiebler, W., Jahn, R., Doucet, J.-P., Rothlein, J., and Greengard, P. (1986) J. Biol. Chem. 261, 8383-8390

91. Bahler, M., and Greengard, P. (1987) Nature 326, 704-707

92. Jovanovic J. N., Benfenati, F., Siow, Y. L., Sihra, T. S., Sanghera J. S., Pelech, S. L., Greengard, P., and Czernik, A. J. (1996) Proc. Natl. Acad. Sci. USA 93, 3679-3678

93. Linder, R., and Ungewickell, E. (1992) J. Biol. Chem. 267, 16567-16573

94. Lafer, E. M., Womack, M., Zhao, X., Prasad, K., and Augustine, G. J. (1997) Soc. Neurosci. Abstr. 23: 361

95. Maycox, P. R., Link, E., Reetz, A., Morris, S. A., and Jahn, R. (1992) J. Cell Biol. 118, 1379-1388

96. Ye, W., and Lafer, E. M. (1995) J. Neurosci. Res. 41, 15-26

97. Murphy, J. E., Hanover, J. A., Froelich, M., Dubois, G., and Keen, J. H. (1994) J. Biol Chem. 269, 21346-21352

98. Alzheimer, A. (1907) All. Z. Psychiatr. 64, 146-148

99. Wisniewski, H. M., Narang, H. K., and Terry, R. D. (1976) J. Neurol. Sci. 27, 173-181

100. Glenner, G. G., and Wong, C. W. (1984) Biochem. Biophys. Res. Comm. 120, 885-890

101. Masters, C. L., Simms, G., Weinman, N. A., Multhaup, G., McDonald, B. L., and Beyreuther, K. (1985) Proc. Natl. Acad. Sci. USA 82, $4245-4249$

102. Kang, J., Lemaire, H.-G., Unterbeck, A., Salbaum, J. M., Masters, C. L., Grzeschik, K. H., Multhaup, G., Beyreuther, K., and Muller-Hill, B. (1987) Nature 325, 733-736

103. Grundke-Iqbal, I., Iqbal, K., Quinlan, M. et al. (1986) J. Biol. Chem. 261, 6084-6089

104. Yen, S.-H., Dickson, D. W., Crowe, A. et al. (1987) Am. J. Pathol. 126, 63-73

105. Goedert, M., Wischik, C. M., Crowther, R. A. et al. (1988) Proc. Natl. Acad. Sci. USA 85, 4051-4055

106. Kosik, K. S., Orecchio, L. D., Binder, L., et al. (1988) Neuron 1, 817-825

107. Spillantini, M. G., and Goedert, M. (1998) Trends Neurosci. 21, 428-433 
108. Arriagada, P.V., Growdon, J.H., Hedley-White, E.T., and Hymann, B.T. (1992) Neurology 42, 631-639

109. Neve, R. L., and Robakis, N. K. (1998) Trends Neurosci. 21, 15-19

110. Lee, V.M.Y. (1996) Ann. NY Acad. Sci. 777, 107-113

111. Hanger, D.P., Betts, J. C., Loviny, T.L., Blackstock, W. P., and Anderton, B. H. (1998) J. Neurochem. 71, 2465-2476

112. Johnson, G.V.W., and Jenkins, S.M. (1996) Alzheimer's Dis. Rev. 1, 38-54

113. Johnson, G.V.W., and Hartigan, J.A. (1998) Alzheimer's Dis. Rev. 3, 125-141

114. Sims, N.R. (1990) Ann. Neurol. 6, 691-693

115. Marcus, D.L., de Leon, M. J., Goldman, J., Logan, J., Christman, D. R., Wolf, A. P., Fowler, J. S., Hunter, K., Tsai , J., Pearson, J., et al. (1989) Ann. Neurol. 1, 91-94

116. Yki- Jarvinen, H., Vogt, C., Iozzo, P., Pipek, R., Daniels, M.C., Virkamaki, A., Makimattila, S., Mandarino, L., DeFronzo, R.A., McClain, D., and Gottschalk, W.K. (1997) Diabetologica 40, 76-81

Received on September 10,1999, accepted on October 17, 1999

\section{Profile of Authors}

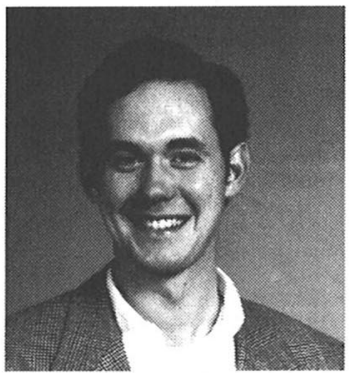

Shane Arnold is a graduate student in the Department of Biochemistry and Molecular Genetics at the University of Alabama at Birmingham. He is completing his doctoral work on the dynamics of cytoskeletalOGlcNAcylation and the O-GlcNAcylation of the microtubule-associated protein tau with Dr. Hart at the Johns Hopkins University School of Medicine. Shane received his Bachelor's degree in Cell and Molecular Biology from Tulane University in May of 1993. Prior to joining Dr. Hart's group, he investigated the signalling of the growth hormone receptor with Dr. Stuart Frank at the University of Alabama at Birrmingham in addition to studying the metabolism of oxidatively modified lipoproteins with Dr. John DeLamatre at Louisiana State University Medical Center.

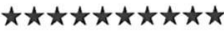

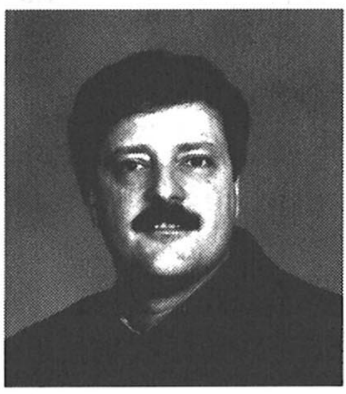

Gerald W. Hart is Director and Professor of Biological Chemistry at Johns Hopkins University School of Medicine. He received his Ph.D. in Developmental Biology at Kansas State University, USA in 1977, and did postdoctoral work in the laboratory of William J. Lennarz at Johns Hopkins prior to joining the faculty there in 1979. He is the founding Editor-InChief of Glycobiology and serves on the editorial board of The Journal of Biological Chemistry. His research is focused on elucidating the biological significance of the dynamic glycosylation of nuclear and cytoplasmic regulatory proteins. 